\title{
Virtual Special Issue on sustainability issues of by- product and waste management systems to produce building material commodities
}

DOI:

10.1016/j.resconrec.2017.07.039

\section{Document Version}

Final published version

Link to publication record in Manchester Research Explorer

\section{Citation for published version (APA):}

Ingrao, C., Arcidiacono, C., Bezama, A., loppolo, G., Winans, K. S., Koutinas, A., \& Gallego Schmid, A. (2017). Virtual Special Issue on sustainability issues of by-product and waste management systems to produce building material commodities: Call of papers. Resources, Conservation and Recycling, 126, 04-05.

https://doi.org/10.1016/j.resconrec.2017.07.039

\section{Published in:}

Resources, Conservation and Recycling

\section{Citing this paper}

Please note that where the full-text provided on Manchester Research Explorer is the Author Accepted Manuscript or Proof version this may differ from the final Published version. If citing, it is advised that you check and use the publisher's definitive version.

\section{General rights}

Copyright and moral rights for the publications made accessible in the Research Explorer are retained by the authors and/or other copyright owners and it is a condition of accessing publications that users recognise and abide by the legal requirements associated with these rights.

\section{Takedown policy}

If you believe that this document breaches copyright please refer to the University of Manchester's Takedown Procedures [http://man.ac.uk/04Y6Bo] or contact uml.scholarlycommunications@manchester.ac.uk providing relevant details, so we can investigate your claim.

\section{OPEN ACCESS}




\title{
Sustainability issues of by-product and waste management systems to produce building material commodities
}

\author{
Carlo Ingrao ${ }^{\mathrm{a}}$, Claudia Arcidiacono ${ }^{\mathrm{b}, *}$, Alberto Bezama ${ }^{\mathrm{c}}$, Giuseppe Ioppolo ${ }^{\mathrm{d}}$, Kiara Winans ${ }^{\mathrm{e}}$, \\ Apostolis Koutinas ${ }^{\mathrm{f}}$, Alejandro Gallego-Schmid ${ }^{\mathrm{g}}$ \\ ${ }^{\text {a }}$ Faculty of Engineering and Architecture, Kore University of Enna, Enna, Italy \\ b Department of Agriculture, Food and Environment (Di3A), University of Catania, Catania, Italy \\ c Helmholtz Centre for Environmental Research - UFZ, Leipzig, Germany \\ d Department of Economics, University of Messina, Messina, Italy \\ e Department of Civil \& Environmental Engineering, Agricultural Sustainability Institute, University of California \\ ${ }^{\mathrm{f}}$ Department of Food Science and Human Nutrition, Agricultural University of Athens, Greece \\ ${ }^{g}$ School of Chemical Engineering and Analytical Science, The University of Manchester, Manchester, United Kingdom
}

Buildings is definitively recognised as one of the most energy demanding sector due to the consumption of energy which, indeed, represents around $40 \%$ of the energy demands at the global level. However, both the operational and the embodied energy should be considered when investigating the life cycle of a building. The operational energy is the one spent to maintain the inside environment through a series of processes, such as heating and cooling, lighting and operating building appliances. Whilst, the embodied energy is sequestered in buildings and building materials during all processes of production, on-site construction, and final demolition and disposal: direct and indirect energy are the two primary components of the embodied energy. The direct component is used for construction, maintenance, renovation and demolition of buildings, whilst the indirect one is consumed for production of the materials utilised for building construction (Ingrao et al., 2016).

Therefore, the selection of less energy and resource demanding materials is an essential element to be accounted for in the design of a building for reduction of both the energy consumption and the environmental impact associated with its life cycle. A valid solution in this sense could be the usage of materials produced from by-products and/ or wastes, as documented in several studies available in the subject literature. For instance, Intini and Kühtz (2011) and Ingrao et al. (2014) assessed, from an environmental perspective, the production of polyester fibre mats for building thermal insulation obtained from postconsumer bottles made of Polyethylene Terephthalate (PET). Both studies highlighted, indeed, that the utilisation of such a waste material enables environmental gains that highly compensate the impacts coming from the most harmful processes involved. This makes such insulating mats environmentally competitive compared to those, also of natural origin, that are currently available in the market with equal function (Ingrao et al., 2014). Environmental benefits in the field of recycled materials for application in buildings were also documented by Rincon et al. (2014) specifically for rubber obtained from recycling of out-use tires. As a matter of fact, the authors performed Life Cycle Assessment (LCA) and emphasised upon the potential of using this material to form drainage layer for extensive green roofs and compared results with conventional roof systems.

The generation and management of wastes are increasingly gaining international attention, and represent two main focuses of the environmental strategies and policies that have been developed thus far by the European Union (Mondello et al., 2017). Several regulations have been, indeed, promoted over the years to: pursue environmental objectives and preventing possible risks to human health; and introduce numerous innovations in the classification of wastes as well as in the ways for their recovery or disposal. Only if affordable, effective and truly sustainable, waste management can be an important factor for sustainable development (Goulart Coelho and Lange, 2016). It can, indeed, contribute to reduction of the cannibalisation phenomenon that is currently occurring for material and energy resources, due to the increasing globalisation and industrialisation (Govindan, 2015). To this end, waste management policies should be focussed not only upon traditional disposal scenarios like landfilling but, also, upon integrated strategies for: development and optimisation of separate-municipalcollection systems; and more environmentally sustainable disposal scenarios, like recycling. Landfill can be an expensive option if the cost of resource depletion and environmental pollution are considered, whilst recycling not only increases the efficiency of resources but, also, reduces environmental burdens (Zaman and Swapan, 2016).

Hence, sustainable integrated waste management systems should be implemented to minimise, through a complex of measures and actions, the environmental impact associated with the management of solid wastes (from collection to treatment), and favour their recovery and

\footnotetext{
* Corresponding author.

E-mail addresses: carlo.ingrao@unikore.it (C. Ingrao), claudia.arcidiacono@unict.it (C. Arcidiacono), alberto.bezama@ufz.de (A. Bezama), giuseppe.ioppolo@unime.it (G. Ioppolo), kswinans@ucdavis.edu (K. Winans), akoutinas@aua.gr (A. Koutinas), alejandro.gallegoschmid@manchester.ac.uk (A.G. Schmid).
} 
recycling (Põldnurk, 2015).

Within this context, it is no surprise that the valorisation of wastes through sustainable management scenarios has become a global matter that is increasingly receiving the attention and interest of researchers, producers, and decision and policy makers. It has multiple key-roles for the sustainability of a huge number of sectors (Valenti et al., 2017), like buildings, and can contribute to sustainable development pathways at the urban and rural context.

Unfortunately, a major competition is recorded nowadays upon byproduct and waste streams, as they are increasingly entering the production of material commodities usable in a wide range of sectors, including buildings. This is the instance case of straw that is by now widely accepted and treated as a cereal cultivation by-product, and is increasingly being utilised in buildings as enveloping material with insulation function.

Hence, investigation and research is desirable for innovation and improvement and, for that, studies should be developed with the aim of: addressing technological, logistics, environmental, socio-economy, market, governance, legislation and policy aspects for the sustainability of waste management systems; and supporting the development of sustainability-oriented strategies, guidelines, legislations and policies.

Overall, the guest editors believe that such research areas and topics are of so great focus and interest to warrant the implementation of a Virtual Special Issue1 (VSI) in this journal to collect those studies and so contribute to the enrichment of the subject literature.

This VSI was designed to motivate prominent researchers to explore the relevance of addressing, and possibly interconnecting, those aspects for the assessment, improvement, encouragement and promotion of sustainability of by-product and waste management systems for production of materials usable in urban and rural buildings.

By doing so, the special issue will possibly serve as a platform to exchange knowledge on emerging methods, practical implementations, state-of-the-arts analyses, findings and lessons learned.

The final aim is to boost and favour the transition towards societies and economies where those by-product and waste streams are managed in more responsible and sustainable manners, and so processed into green materials, including those usable in buildings.

Authors are invited to submit their original-research and/or review papers that make relevant contributions within this scope. However, they are discouraged from submitting manuscripts that only present results from laboratory experiments and technical studies. All the peer-review ready papers that are submitted should, indeed, be characterised by a clear discussion about: the novelty aspects and the contributions to the subject knowledge and literature; and the practical, environmental and socio-economic implications of the researches that they report upon. We expect contributions that investigate one or more of those aspects within this scope, with the final aim of providing insights upon the current and likely-future trends of sustainability in the field of waste valorisation and recovery for more sustainable buildings. In the spirit and overall scope of the journal, those contributions should also emphasise upon the transformation processes and implications being involved in the transition towards more sustainable production, transportation and utilisation systems.

\section{Submission Format and Guideline}

All submitted papers must contain only original work, which has not been published by or is currently under review for any other journal or conference. A detailed submission guideline is available as "Guide for Authors" at: http://www.journals.elsevier.com/resources-conservation-andrecycling.

All manuscripts and any supplementary material should be submitted through Elsevier Editorial System (http://ees.elsevier.com/ recycl). The authors must select "VSI: Waste for buildings" in the submission process.

\section{Important dates}

Peer-review ready paper submission deadline: December 31, 2017 Final decision notification deadline: May 31, 2018 Publication of special issue: as soon as accepted (VSI)

\section{References}

Goulart Coelho, L.M., Lange, L.C., 2016. Applying life cycle assessment to support environmentally sustainable waste management strategies in Brazil. https://doi.org/ Resour. Conserv. Recy. http://dx.doi.org/10.1016/j.resconrec.2016.09.026.

Govindan, K., 2015. Green sourcing: Taking steps to achieve sustainability management and conservation of resources. Resour. Conserv. Recy. 104, 329-333.

Ingrao, C., Lo Giudice, A., Tricase, C., Rana, R., Mbohwa, C., Siracusa, V., 2014. RecycledPET fibre based panels for building thermal insulation: environmental impact and improvement potential assessment for a greener production. Sci. Total Environ. 493, 914-929.

Ingrao, C., Scrucca, F., Tricase, C., Asdrubali, F., 2016. A comparative Life Cycle Assessment of external wall-compositions for cleaner construction solutions in buildings. J. Clean. Prod. 124, 283-298.

Intini, F., Kühtz, S., 2011. Recycling in buildings: an LCA case study of a thermal insulation panel made of polyester fiber, recycled from post-consumer PET bottles. Int. J. Life Cycle Assess. 16, 306-315.

Mondello, G., Salomone, R., Ioppolo, G., Saija, G., Sparacia, S., Lucchetti, M.C., 2017. Comparative LCA of Alternative Scenarios for Waste Treatment: The Case of Food Waste Production by the Mass-Retail Sector. Sustainability 2017 (9), 1-18.

Põldnurk, J., 2015. Optimisation of the economic, environmental and administrative efficiency of the municipal waste management model in rural areas. Resour. Conserv. Recy. 97, 55-65.

Rincon, L., Coma, J., Perez, G., Castell, A., Boer, D., Cabeza, L.F., 2014. Environmental performance of recycled rubber as drainage layer in extensive green roofs. A comparative Life cycle Assessment. Build. Environ 74, 22-30.

Valenti, F., Porto, S.M.C., Chinnici, G., Selvaggi, R., Cascone, G., Arcidiacono, C., Pecorino, B., 2017. Use of citrus pulp for biogas production: A GIS analysis of citrusgrowing areas and processing industries in South Italy. Land Use Policy 66, 151-161.

Zaman, A.U., Swapan, M.S.H., 2016. Performance evaluation and benchmarking of global waste management systems. Resour. Conserv. Recy. 114, 32-41.

\footnotetext{
${ }^{1}$ A Virtual Special Issue (VSI) is an online-only grouping of Special Issue articles traditionally assigned to a single Special Issue. Each article in a VSI is assigned a unique identifier and then published in a regular journal issue as soon as available. The unique identifier allows us to simultaneously add the article to a VSI on ScienceDirect which is gradually built up as individual articles are published online. Articles grouped together in a VSI retain their original citation details. A VSI speeds up the publication of individual articles as, unlike the publication process for conventional Special Issue articles, a VSI does not need to wait for the final article to be ready before publication.
} 